Nitrogen dioxide $\left(\mathrm{NO}_{2}\right)$ is a common indoor and outdoor air pollutant whose role in the induction of asthma is unclear. We investigated the effects of $\mathrm{NO}_{2}$ on the development of asthma-like responses to allergenic challenge in BALB/c mice. Ovalbumin (OVA)-immunized mice were intranasally challenged with OVA or saline solution just before starting a $3 \mathrm{~h}$ exposure to 5 or $20 \mathrm{ppm} \mathrm{NO}_{2}$ or air. Twenty parts per million of $\mathrm{NO}_{2}$ induced a significant increase of bronchopulmonary hyperreactivity in OVA-challenged mice and of permeability according to the fibronectin content of the bronchoalveolar lavage fluid (BALF) $24 \mathrm{~h}$ after exposure, as compared with air or $5 \mathrm{ppm} \mathrm{NO}_{2}$. Eosinophilia (cell counts in the BALF and eosinophil peroxidase of lung tissue) was detected at 24 and $72 \mathrm{~h}$ with similar levels for air and 20 ppm $\mathrm{NO}_{2}$, whereas a marked reduction was unexpectedly observed for $5 \mathrm{ppm} \mathrm{NO}$. At $24 \mathrm{~h}$, interleukin5 in the BALF was markedly reduced at $5 \mathrm{ppm}$ compared with $20 \mathrm{ppm} \mathrm{NO}_{2}$ and was also more intense for $20 \mathrm{ppm} \mathrm{NO}_{2}$ than for the air group. In contrast to specific IgG1 titers, anti-OVA IgE titers and interleukin- 4 in the BALF were not affected by $\mathrm{NO}_{2}$ exposure. Irrespective of the concentration of $\mathrm{NO}_{2}$, OVA-challenged mice did not develop late mucosal metaplasia compared with those exposed to OVA-air. These results indicate that a short exposure to $\mathrm{NO}_{2}$ can exacerbate or inhibit some features of the development of allergic disease in mice and may depend on the concentration of pollutant.

Key words: Mouse model of asthma, Nitrogen dioxide, Air pollutant, Bronchopulmonary hyperreactivity, Lung permeability, Eosinophilia, Mucus

\section{Interference of a short-term exposure to nitrogen dioxide with allergic airways responses to allergenic challenges in BALB/c mice}

\author{
Barbara Proust ${ }^{1,2}$, Ghislaine Lacroix ${ }^{2}$, \\ Franck Robidel ${ }^{2}$, Maryse Marliere ${ }^{2}$, \\ Anthony Lecomte ${ }^{2}$ and B. Boris Vargaftig ${ }^{1, C A}$
}

${ }^{1}$ Unité de Pharmacologie Cellulaire, Unité Associée Institut Pasteur - INSERM U485, 25 rue du Docteur Roux, 75724 Paris Cedex 15, France; ${ }^{2}$ Institut National de I'Environnement Industriel et des Risques (INERIS), Verneuil-en-Halatte, France

\author{
${ }^{\mathrm{CA}}$ Corresponding Author \\ Tel: +33145688682 \\ Fax: +3314568 87 03; E-mail: vargafti@pasteur.fr
}

\section{Introduction}

Asthma is an allergic respiratory disease that has captured a great deal of attention for several years. One of its perplexing aspects is that its prevalence has increased steadily during this century, doubling in the past 20 years in most industrialized countries. ${ }^{1}$ Although asthma is familial and genome-wide searches have identified genetic loci predisposing to the disease, it is unlikely that the genetic make-up of stable populations can change significantly in less than one century. The probable cause of the epidemic must therefore relate to the environment. ${ }^{1}$ Several recent studies have shown an association between air pollution during episodes of smog and asthma exacerbations, and hospital visits for asthma. ${ }^{2-4}$ Although this finding does not address causality, it supports air pollution having an effect on acute asthmatic episodes. Current evidence also suggests that asthmatics are more sensitive to the effects of air pollutants. ${ }^{5}$

Asthma is characterized by acute bronchoconstriction, late bronchopulmonary hyperreactivity, pulmo- nary eosinophilic inflammation, excessive mucus production and increased serum IgE titers ${ }^{6}$ induced by a variety of stimuli. Its pathology seems to be directly linked to the presence in the airways of eosinophils and of $\mathrm{T}$ helper 2 (Th2) $\mathrm{CD}^{+}$lymphocytes ${ }^{7,8}$ which produce interleukin (IL)- 4 and IL-5. These Th 2 cytokines are said to play a central role in the initiation and perpetuation of asthma. ${ }^{9}$ IL-5 regulates the growth, differentiation and activation of eosinophils and provides an essential signal for their recruitment to the lungs during allergic inflammation. ${ }^{10} \mathrm{IL}-4$ induces the differential development of $\mathrm{T}$ helper 0 cells into Th2 cells, ${ }^{11}$ and stimulates B lymphocytes to produce IgE. ${ }^{12}$

Nitrogen dioxide $\left(\mathrm{NO}_{2}\right)$, a major potent oxidant pollutant, is a well-known airway irritant. ${ }^{13}$ In contrast to other pollutants, $\mathrm{NO}_{2}$ is a widespread contaminant of outdoor and of indoor environment. Its indoor levels can exceed those found outdoors, and are provided by gas cooking appliances and tobacco smoke. ${ }^{14,15}$ By contrast, the main sources of $\mathrm{NO}_{2}$ in outdoor air are motor vehicle emissions and 
fossil-fuel burning industries. ${ }^{13}$ Acute exposures to high concentrations of $\mathrm{NO}_{2}$ produce changes in pulmonary function, increase airway responsiveness, ${ }^{16}$ and induce pulmonary edema. ${ }^{17} \mathrm{NO}_{2}$ may also cause release of inflammatory mediators, and induce mast cell and lymphocyte infiltration. ${ }^{18}$ Animal studies have demonstrated that exposure to $\mathrm{NO}_{2}$ can increase susceptibility to infection, presumably through its effect on lung defense mechanisms, mucociliary clearance, ${ }^{19}$ and alveolar macrophage function. ${ }^{20,21}$ $\mathrm{NO}_{2}$ is tissue soluble, with unsaturated bonds in membrane lipids of the airway and respiratory epithelium, as well lining fluid, being its prime targets. ${ }^{22}$ Several studies have associated morbidity of asthma with elevated concentrations of $\mathrm{NO}_{2} \cdot{ }^{23,24}$ Based on epidemiological studies, it has been suggested that $\mathrm{NO}_{2}$ increases the risk for exacerbations of asthma. ${ }^{25,26}$ Clinical observations have demonstrated that exposure to $\mathrm{NO}_{2}$ correlates with exacerbations of asthma and with the potentiation of airway reactivity in asthmatics, ${ }^{27,28}$ in contrast to other studies, which have failed to show an association between exposure to $\mathrm{NO}_{2}$ and increased incidence of asthma. ${ }^{29}$ These discrepancies show that the role of $\mathrm{NO}_{2}$ for allergic disease is still unclear.

Since $\mathrm{NO}_{2}$ can increase the bronchial responsiveness to non-specific stimuli such as histamine and methacholine, it may hypothetically affect bronchial responsiveness and other features of asthma to inhaled allergen as well. The existence of such an interaction between $\mathrm{NO}_{2}$ and allergen resulting in an augmented allergic reaction has been suggested. ${ }^{24,27,30}$ In the present study, we investigated the role of $\mathrm{NO}_{2}$ in the exacerbation of asthma in an ovalbumin (OVA)-immunized mouse model. For that, we studied whether a short-term exposure to low or high concentrations of $\mathrm{NO}_{2}$ can potentiate the responses to allergenic challenge in (OVA)-immunized mice, in order to define its possible adjuvant role in the development of some features of asthma, such as bronchopulmonary responsiveness, eosinophilic pulmonary inflammation, production of Th2 cytokines, and of specific IgE and mucus secretion.

\section{Materials and methods}

\section{Animals}

Male strain BALB/c mice (6-7 weeks of age, $23 \pm 2 \mathrm{~g}$ body weight) purchased from the Centre d'Elevage $R$. Janvier (Le Genest Saint-Isle, France) were housed in the INERIS animal-care unit, a facility accredited by the Departmental Direction of Veterinary Services. The animals had free access to conventional laboratory feed and water. Animals were handled in accordance with French State Council guidelines for the care and use of laboratory animals (Decree number 87-849, 19 October 1987), and was approved by the Institutional Animal Care and Use Committee at the INERIS.

\section{Antigen immunization and challenge}

$\mathrm{BALB} / \mathrm{c}$ mice were immunized by the subcutaneous injection of $10 \mu \mathrm{g}$ of OVA (ICN Biomedicals, Inc., Aurora, OH, USA), dispersed in $1.6 \mathrm{mg}$ of $\mathrm{Al}(\mathrm{OH})_{3}$ (Merk, Darmstadt, Germany) in $0.4 \mathrm{ml}$ of $0.9 \% \mathrm{NaCl}$ (saline) at days 0 and 7. At day 14, 1 week after the second injection, immunized mice were intranasally (i.n.) challenged with $10 \mu \mathrm{g}$ of OVA in $50 \mu 1$ of saline for about $10 \mathrm{sec}$ under anesthesia by intravenous injection of ketamine $\left(35 \mathrm{mg} / \mathrm{kg}\right.$ Imalgene ${ }^{\circledR} 1000$; Merial, Lyon, France). Control mice were challenged with the same volume of saline solution.

\section{Exposure system}

The whole body exposure system used to generate $\mathrm{NO}_{2}$ and expose the animals was developed in the laboratory of INERIS. Unrestrained, and conscious mice challenged with OVA or saline were individually placed in a whole body glass chamber of 0.51 and were exposed to 5 or $20 \mathrm{ppm} \mathrm{NO}_{2}$ or to air for $3 \mathrm{~h}$. In each glass chamber, $\mathrm{NO}_{2}$ was delivered with a flow rate of $51 / \mathrm{min}$, allowing one to have a renewal, and was calibrated at the exact desired concentration in synthetic air. The airflow of $\mathrm{NO}_{2}$ in each chamber was monitored by a mass flow-meter during the period of exposure. The relative pressure of the glass exposure chamber was controlled by a manometer. Concentrations of 5 or $20 \mathrm{ppm}$ of $\mathrm{NO}_{2}$ were obtained from cylinders of $\mathrm{NO}_{2}$ gas prepared and certified by the supplier (Air Liquide, Le Blanc Mesnil, France).

\section{Evaluation of bronchopulmonary hyperreactivity}

Bronchopulmonary hyperreactivity (BHR) was evaluated with a barometric plethysmography method. Unrestrained, conscious mice were placed in a whole body plethysmographic chamber (EMKA Technologies, Paris, France) that measured the respiratory waveforms. Animals were exposed to an aerosol of methacholine (Aldrich, Milwaukee, WI, USA) for $20 \mathrm{sec}$ at $0.1 \mathrm{M}$ delivered by an aerosolator. The index of airway obstruction was expressed as enhanced pause $\left(P_{\mathrm{enh}}\right)$, in response to inhaled methacholine, ${ }^{31}$ calculated as: $P_{\mathrm{enh}}=\left[T_{\mathrm{e}} / T_{\mathrm{r}}-1\right] \times\left[P_{\mathrm{ef}} / P_{\mathrm{if}}\right]$, where $T_{\mathrm{e}}$ is expiratory time, $T_{\mathrm{r}}$ is relaxation time, $P_{\mathrm{ef}}$ is peak expiratory flow and $P_{\text {if }}$ is peak inspiratory flow. For the graphic representation, each value was expressed every minute and was calculated from the average of three values of $P_{\text {enh }}$ recorded every $20 \mathrm{sec}$. To simplify the interpretations, the area under the curve was calculated for $15 \mathrm{~min}$. The graphics in terms of area under the curve represent the quantitative expression of BHR. 
Serum sample preparations and bronchoalveolar lavage fluid

Mice were anesthetized by the intraperitoneal injection of urethane $(2 \mathrm{~g} / \mathrm{kg}$ ethylcarbamate; Sigma, St Louis, MO, USA) and the abdominal cavity was opened. Blood samples were collected from the post vena cava, and serum was collected after centrifugation at $500 \times g$ for $10 \mathrm{~min}$ and stored at $-20^{\circ} \mathrm{C}$ until used. After exsanguination, the lungs were flushed via the cannulated trachea with $4 \times 0.5 \mathrm{ml}$ of a sterile phosphate-buffered saline (PBS) solution (phosphate buffer $10 \mathrm{mM}$; pH 7.4). The total cell numbers were counted automatically (Coulter Counter ZM, Coultronics, Margency, France). Bronchoalveolar lavage fluid (BALF) was cytocentrifuged for $10 \mathrm{~min}$ (Cytospin, Shandon, UK). Slides were stained with a MayGrünwald-Giemsa-derived method (Diff Quick; Baxter Dade AG, Duedingen, Switzerland), and a total of 200 cells was counted for each sample by light microscopy, the percentage of each cell population being calculated. The BALF was centrifuged for $10 \mathrm{~min}$ at $1850 \times g, 4^{\circ} \mathrm{C}$ (Jouan, Saint Herblain, France) and the supernatants were removed and stored at $-20^{\circ} \mathrm{C}$ until used.

\section{Evaluation of lung eosinophil peroxidase activity}

To quantify the lung sequestration of eosinophils, eosinophil peroxidase (EPO) activity in the lung was evaluated in 96-well plates by a cytochemical enzyme assay. ${ }^{32}$ Briefly, lungs were removed and homogenized (Potter-Elvejhem glass homogenizer; Thomas, Philadelphia, PA, USA) in 0.05 M Tris-HCl buffer (pH 8) containing $0.1 \%$ Triton X-100 solution. Lung homogenates were centrifuged for $15 \mathrm{~min}$ at $1600 \times g, 4^{\circ} \mathrm{C}$ (Bioblock Scientific 2K15; Sigma, Illkirsh, France). EPO activity was measured in the supernatant, based on the oxidation of $o$-phenylenediamine (Sigma) by EPO in the presence of peroxide hydrogen. Incubations in duplicate were carried out in the absence or presence of the peroxidase inhibitor 3-amino1,2,4-triazole (Sigma). Plates were read with an automatic microplate at $490 \mathrm{~nm}$ and results are expressed as optical density (OD).

\section{Evaluation of cytokines}

IL- 4 in the BALF was evaluated by enzyme-linked immunosorbent assay (ELISA). Briefly, 96-well plates were coated with rat anti-mouse IL-4 (BVD4-1D11; Perbio Sciences, Erembodegem-Aalst, Belgium) at $2 \mu \mathrm{g} / \mathrm{ml}$ diluted in $0.1 \mathrm{M}$ carbonate buffer ( $\mathrm{pH}$ 8.2) and incubated overnight at $4{ }^{\circ} \mathrm{C}$. Plates were washed with PBS/0.1\% Tween 20 and blocked with PBS containing $1 \%$ of bovine serum albumin overnight at $4^{\circ} \mathrm{C}$. After washing, dilutions of recombinant murine
IL-4 (Perbio Sciences) (15.6-1000 pg/ml) or samples were applied overnight at $4^{\circ} \mathrm{C}$. Then, biotinylated rat anti-IL-4 antibody (BVD6-24G2; Perbio Sciences) was added at $0.5 \mu \mathrm{g} / \mathrm{ml}$ for $2 \mathrm{~h}$ at $4^{\circ} \mathrm{C}$. Plates were incubated with ExtrAvidin ${ }^{\circledR}$ peroxidase conjugate (1:2000 to each well; Sigma) for $45 \mathrm{~min}$ at room temperature (RT). Plates were developed with tetramethylbenzidine substrate (Kiregaard Perry Laboratories, MD, USA). The reaction was stopped with $2 \mathrm{~N}$ sulfuric acid and the plates were read at $450 \mathrm{~nm}$ with an automatic microplate reader. The lower limit of detection of this assay is $\sim 10 \mathrm{pg}$ of $\mathrm{IL}-4 / \mathrm{ml}$ sample.

IL-5 in the BALF was quantified using an immunometric assay as described previously. ${ }^{33}$ Briefly, 96-well plates were coated with $10 \mu \mathrm{g} / \mathrm{ml}$ of rat anti-mouse IL5 (TRFK-4). To these were added dilutions of recombinant IL-5 standard $(7.6-1000 \mathrm{pg} / \mathrm{ml})$ or of the sample, followed by an acetylcholinesterase-labelled rat antimouse IL-5 antibody (TRFK-5) at 10 Elman units/ml. Absorbance was read at $405 \mathrm{~nm}$ with an automatic microplate reader. The lower limit of detection of this assay is $\sim 5 \mathrm{pg}$ of IL- $5 / \mathrm{ml}$ sample.

\section{Evaluation of anti-OVA specific IgE and IgG1}

The specific anti-OVA specific IgE and IgG1 in the serum were measured by ELISA. For the determination of specific IgE, 96-well plates were coated with rat anti-mouse IgE (EM 95-3) at $5 \mu \mathrm{g} / \mathrm{ml}$ diluted in $0.5 \mathrm{M}$ carbonate buffer ( $\mathrm{pH}$ 9.6) and incubated overnight at $4^{\circ} \mathrm{C}$. The next day, plates were washed with PBS/0.1\% Tween 20 and blocked with PBS containing $1 \%$ of bovine serum albumin (BSA) for $2 \mathrm{~h}$ at RT. After blocking, plates were washed and serum samples were added and incubated overnight at $4^{\circ} \mathrm{C}$. The plates were then washed and $10 \mu \mathrm{g} / \mathrm{ml}$ of biotinylated OVA was added. The remaining steps were performed exactly as described for IL- 4 .

For the evaluation of specific IgG1, 96-well plates were coated with OVA (ICN Biomedicals) at $10 \mu \mathrm{g} / \mathrm{ml}$ diluted in $0.1 \mathrm{M}$ carbonate buffer $(\mathrm{pH}$ 8.2) and incubated overnight at $4^{\circ} \mathrm{C}$. Plates were washed with PBS/0.1\% Tween 20 and blocked with PBS containing $1 \%$ of BSA for $1 \mathrm{~h}$ at $37^{\circ} \mathrm{C}$. After blocking and washing, serum samples were added and incubated for $1 \mathrm{~h}$ at $37^{\circ} \mathrm{C}$. Plates were washed and incubated with Goat anti-mouse IgG1 alkaline phosphatase conjugate (1:2000 to each well; Caltag Laboratories, Burlingame, CA, USA) for $1 \mathrm{~h}$ at $37^{\circ} \mathrm{C}$. The colorimetric reaction was initiated with $p$-nitrophenylphosphate $(1 \mathrm{mg} / \mathrm{ml})\left(\right.$ Sigma) at $37^{\circ} \mathrm{C}$. Plates were read at $405 \mathrm{~nm}$ with an automatic microplate reader.

As a positive control, serum pooled from OVAimmunized and challenged mice was used. Data from serum samples were expressed according to the absorbance of positive control serum after subtracting the buffer-only blank data from both. An index 
was calculated as: IgE or IgG1 index $=(\mathrm{OD}$ sample OD buffer only) / (OD positive control - OD buffer only).

\section{Evaluation of fibronectin}

To evaluate the intensity of exudation through the airways, fibronectin in the BALF was measured by the indirect competitive ELISA method described by Rennard et al. ${ }^{34}$ Briefly, 96-well plates were coated with murine fibronectin (Anawa, Wangen, Switzerland) at $1 \mu \mathrm{g} / \mathrm{ml}$ diluted in $0.02 \mathrm{M}$ carbonate buffer (pH 9.6) and incubated overnight at $4^{\circ} \mathrm{C}$. In another 96-well plates, BALF samples and standard fibronectin were incubated with a polyclonal rabbit anti-fibronectin antibody (1:10000; Anawa). The next day, plates coated with fibronectin were washed with PBS/0.1\% Tween 20 and blocked with PBS containing $1 \%$ of BSA for $2 \mathrm{~h}$ at RT. Then, plates were rinsed with PBS/0.1\% Tween 20 and $100 \mu 1$ of antigen-antibody were applied to the plates and incubated for $2 \mathrm{~h}$ at RT. After washing, the anti-fibronectin antibody that did not bind with BALF fibronectin content was detected with a biotinylated secondary anti-rabbit antibody (1:1500; Amersham Pharmacia Biotech, Orsay, France) and incubated for $2 \mathrm{~h}$ at RT. Plates were washed and incubated with ExtrAvidin ${ }^{\circledR}$ peroxidase conjugate (1:20000 to each well; Sigma) for $45 \mathrm{~min}$ at RT. The remaining steps were performed exactly as described for IL- 4 . The lower limit detection of this assay is $\sim 0.078 \mu \mathrm{g}$ of fibronectin $/ \mathrm{ml}$ sample.

\section{Lung histology}

After exsanguination, the lungs were removed and fixed by intratracheal instillation with $10 \%$ neutral phosphate-buffer formalin. The whole lung was embedded in paraffin, sectioned at a thickness of $5 \mu \mathrm{m}$ and stained with periodic acid Schiff to examine mucus cells in the airway walls.

\section{Statistical analysis}

The results are expressed as mean \pm standard error of the mean (SEM). Statistical comparisons between groups were made using analysis of variance. Multiple comparisons between all groups were performed by Fisher's least-significant difference test. $p \leq 0.05$ was considered significant.

\section{Results}

To investigate the influence of $\mathrm{NO}_{2}$ on the responses to the i.n. administration of OVA in immunized mice, two concentrations of $\mathrm{NO}_{2}$ that are relatively high compared with those encountered in the environment were used, since the actual amounts delivered to the lung are quite below the concentrations

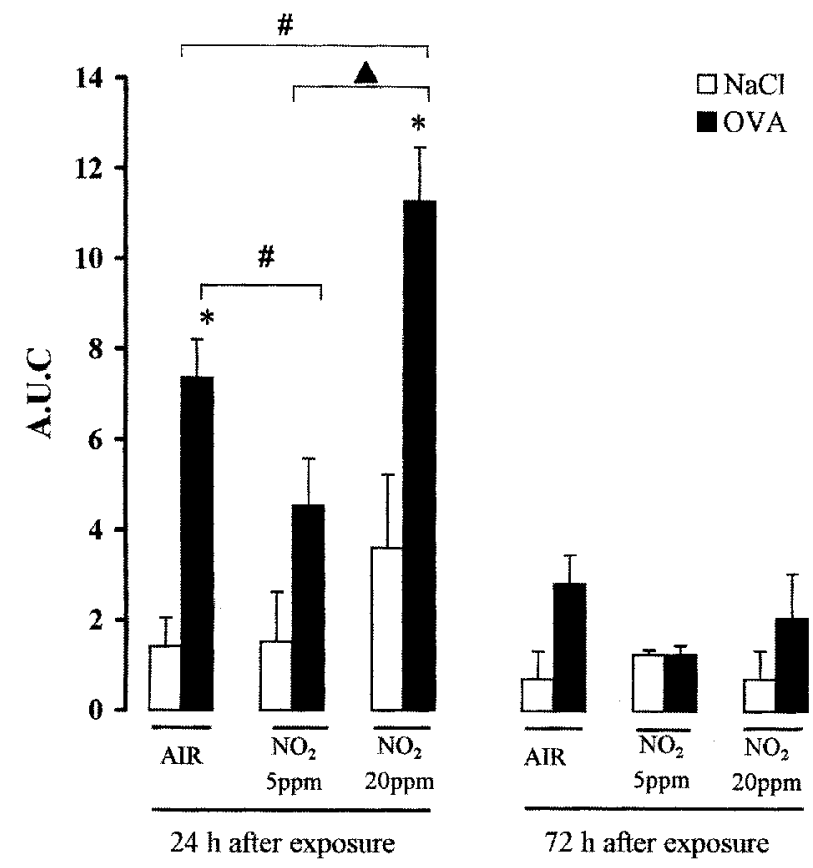

FIG. 1. BHR is significantly augmented in immunized mice exposed to $20 \mathrm{ppm} \mathrm{NO}_{2}$. At day 14, immunized mice were challenged i.n. with saline ( $\square$ ) or OVA ( $\square$ ) and were exposed to 5 or $20 \mathrm{ppm} \mathrm{NO} \mathrm{NO}_{2}$ or to air for $3 \mathrm{~h}$. At days $15(24 \mathrm{~h})$ and 17 (72 h), BHR in response to methacholine was evaluated. The graphic in terms of area under the curve (A.U.C) represents the quantitative expression of BHR. Data are expressed as the mean \pm SEM. ${ }^{*} p \leq 0.05$, OVA-challenged mice compared with their saline control; ${ }^{*} p \leq 0.05$, OVA-air group compared with the $\mathrm{NO}_{2}$-OVA group (5 or $20 \mathrm{ppm}$ ); $\quad p \leq 0.05,5 \mathrm{ppm}$ $\mathrm{NO}_{2}$-OVA group compared with the $20 \mathrm{ppm} \mathrm{NO}_{2}$-OVA group.

inhaled. ${ }^{35,36}$ We have developed a murine model of allergen-induced pulmonary inflammation sharing the essential features of asthma, in which the two time points of 24 and $72 \mathrm{~h}$ after allergenic challenge allow one to evaluate the parameters of the asthma phenotype. One week after the booster injection of antigen, OVA-immunized mice were challenged i.n. with $10 \mu \mathrm{g}$ of OVA or saline just before the exposure to air or to $\mathrm{NO}_{2}$ at 5 or $20 \mathrm{ppm}$ for $3 \mathrm{~h}$. The time points of 24 and $72 \mathrm{~h}$ were studied after $\mathrm{NO}_{2}$ exposure. The peak of BHR, the initial phase of pulmonary eosinophil entrapment, and the peak of production of Th2 cytokines were studied at $24 \mathrm{~h}$, whereas at $72 \mathrm{~h}$ the increase of pulmonary eosinophilic inflammation, the late mucosal metaplasia development and specific immunoglobulins in serum were determined.

\section{Bronchopulmonary responsiveness to methacholine}

At day 15 (i.e. $24 \mathrm{~h}$ after the exposure to $20 \mathrm{ppm} \mathrm{NO}_{2}$ or to air), immunized BALB/c mice challenged with OVA expressed significant BHR as compared with those exposed to $5 \mathrm{ppm} \mathrm{NO} \mathrm{NO}_{2}$ (Fig. 1). Mice challenged with saline exposed to air or to $\mathrm{NO}_{2}$ did not develop BHR. In OVA-challenged mice exposed to $20 \mathrm{ppm}$ 


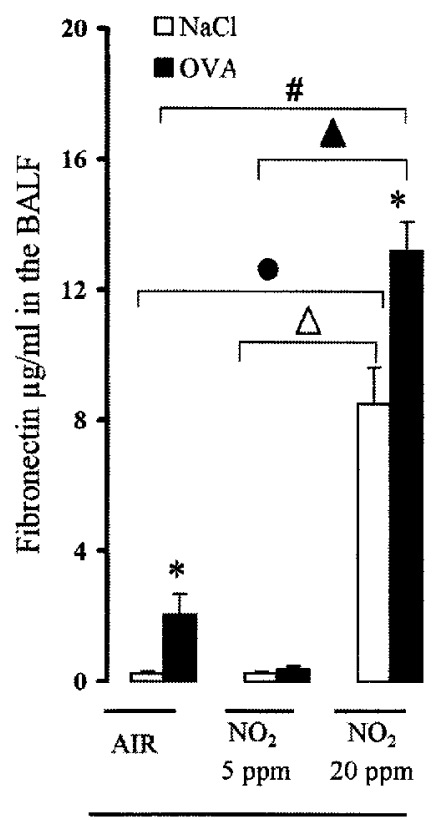

$24 \mathrm{~h}$ after exposure

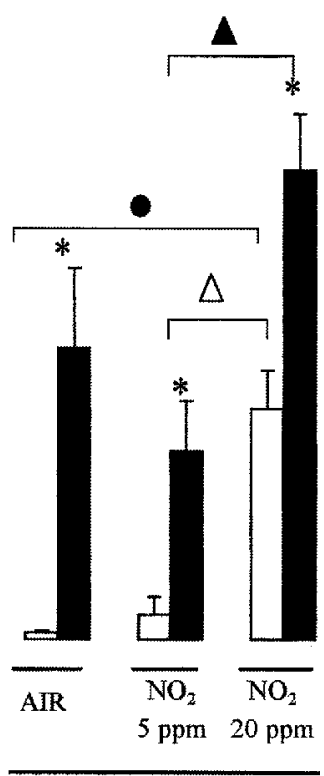

$72 \mathrm{~h}$ after exposure

FIG. 2. BALF fibronectin content after short exposure to $\mathrm{NO}_{2}$. At day 14 , immunized mice were challenged i.n. with saline $(\square)$ or OVA $(\square)$ and were exposed to 5 or $20 \mathrm{ppm} \mathrm{NO}$ or to air for $3 \mathrm{~h}$. At days $15(24 \mathrm{~h})$ and $17(72 \mathrm{~h})$ after exposure, mice were sacrificed. Fibronectin levels were evaluated in the BALF by ELISA. Data are expressed as the mean \pm SEM. ${ }^{*} p \leq$ 0.05 , OVA-challenged mice compared with their saline control; ${ }^{\#} p \leq 0.05$, OVA-air group compared with the $\mathrm{NO}_{2}$ OVA group (5 or $20 \mathrm{ppm}$ ); $\bullet p \leq 0.05$, saline-air group compared with the $\mathrm{NO}_{2}$-saline group (5 or $20 \mathrm{ppm}$ ); ${ }^{\wedge} p \leq 0.05$, $5 \mathrm{ppm} \mathrm{NO} \mathrm{N}_{2}$-OVA group compared with the $20 \mathrm{ppm} \mathrm{NO} \mathrm{N}_{2}$-OVA group; ${ }^{\triangle} p \leq 0.05,5 \mathrm{ppm} \mathrm{NO} \mathrm{N}_{2}$-saline group compared with the $20 \mathrm{ppm} \mathrm{NO} \mathrm{N}_{2}$-saline group.

$\mathrm{NO}_{2}$, BHR was significantly increased as compared with those exposed to air and to $5 \mathrm{ppm} \mathrm{NO}_{2}$. At day $17,72 \mathrm{~h}$ after exposure, OVA-challenged mice exposed to air or to $\mathrm{NO}_{2}$ failed to develop BHR (Fig. 1).

\section{Fibronectin exudation into the BALF}

To evaluate the exudation through the airways, the concentration of fibronectin was measured in the BALF. OVA-challenged mice exposed to air or to $20 \mathrm{ppm} \mathrm{NO} \mathrm{N}_{2}$ released significantly increased amounts of fibronectin in the BALF, whereas those levels were very low in animals exposed to $5 \mathrm{ppm} \mathrm{NO}_{2}$ (Fig. 2). In contrast, exposure to $20 \mathrm{ppm} \mathrm{NO}_{2}$ augmented by sixto seven-fold the fibronectin concentrations in the BALF of OVA-challenged mice after $24 \mathrm{~h}$, as compared with the OVA-air group. $\mathrm{NO}_{2}$ at $20 \mathrm{ppm}$ also induced a marked fibronectin exudation in saline-challenged mice, as compared with the saline-air or saline- $5 \mathrm{ppm}$ $\mathrm{NO}_{2}$ groups. Seventy-two hours after exposure, BALF fibronectin content persisted in saline- or OVAchallenged mice exposed to $20 \mathrm{ppm} \mathrm{NO}_{2}$. At this time point, in OVA-challenged mice exposed to $5 \mathrm{ppm} \mathrm{NO}_{2}$

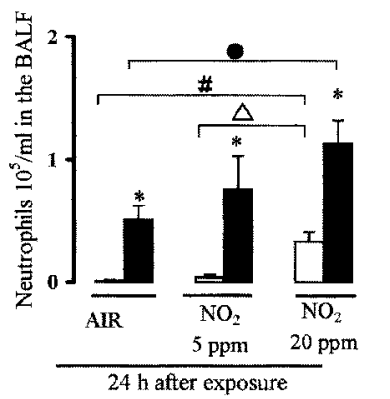

A

$\square \mathrm{NaCl}$

mOVA
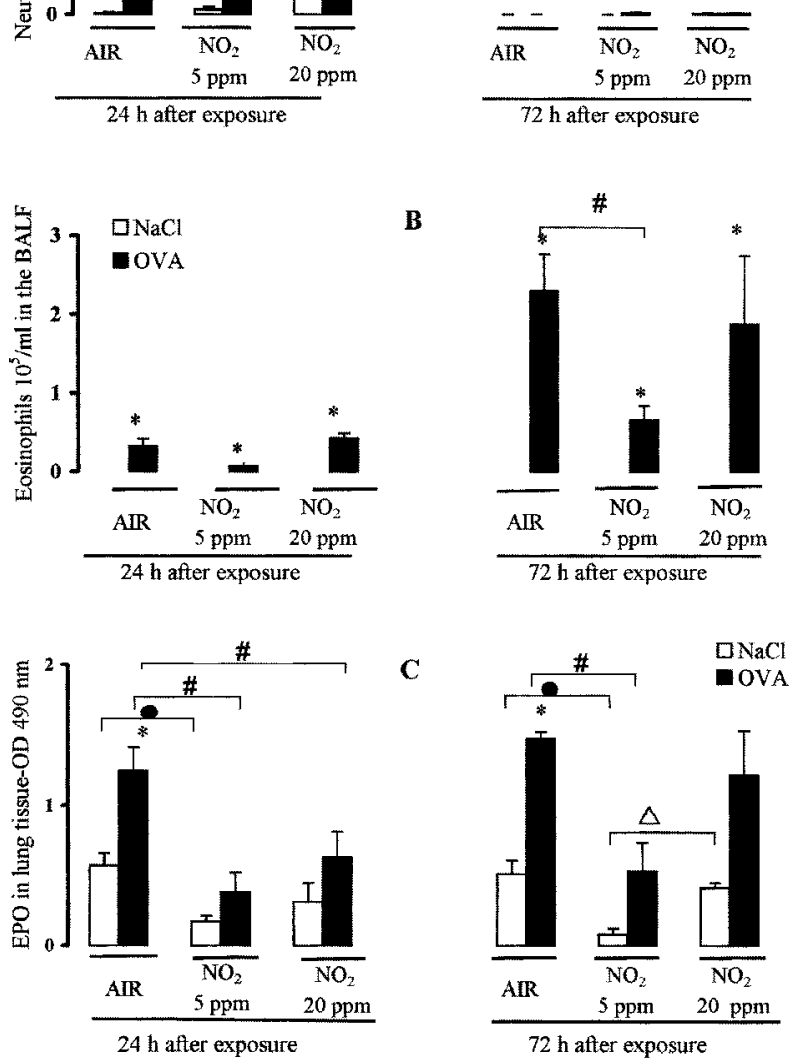

FIG. 3. BALF cell infiltration after exposures to $\mathrm{NO}_{2}$. At day 14 , immunized mice were treated as in Fig. 2 (saline ( $\square$ ) or OVA ( $\square)$ ). Differential BALF cell counts and EPO of the lungs were evaluated. (A) Neutrophils, (B) eosinophils and (C) eosinophil peroxidase. Data are expressed as the mean \pm SEM. ${ }^{*} p \leq 0.05$, OVA-challenged mice compared with their saline control; " $p \leq 0.05$, OVA-air group compared with the $\mathrm{NO}_{2}$-OVA group (5 or $20 \mathrm{ppm}$ ); $p \leq 0.05$, saline-air group compared with the $\mathrm{NO}_{2}$-saline group (5 or $20 \mathrm{ppm}$ ); ${ }^{\mathbf{\Lambda}} p \leq 0.05$, $5 \mathrm{ppm} \mathrm{NO} \mathrm{N}_{2}$-saline group compared with the $20 \mathrm{ppm} \mathrm{NO}_{2}-$ saline group.

or to air, the release of fibronectin was delayed, as compared with mice exposed to $20 \mathrm{ppm} \mathrm{NO}_{2}$ (Fig. 2). Indeed, $24 \mathrm{~h}$ after exposure to air or to $5 \mathrm{ppm} \mathrm{NO}_{2}$, no or low fibronectin was detected in the BALF of OVA-challenged mice. But, $72 \mathrm{~h}$ after exposure, increased amounts of fibronectin were found, contrary to mice exposed to $20 \mathrm{ppm} \mathrm{NO}_{2}$, in which exudation started at $24 \mathrm{~h}$.

\section{BALF cell infiltration and lung sequestration of eosinophils}

At $24 \mathrm{~h}$, neutrophil counts were increased in the BALF of OVA-challenged mice exposed to air or to $\mathrm{NO}_{2}$. These counts were found significantly increased and 


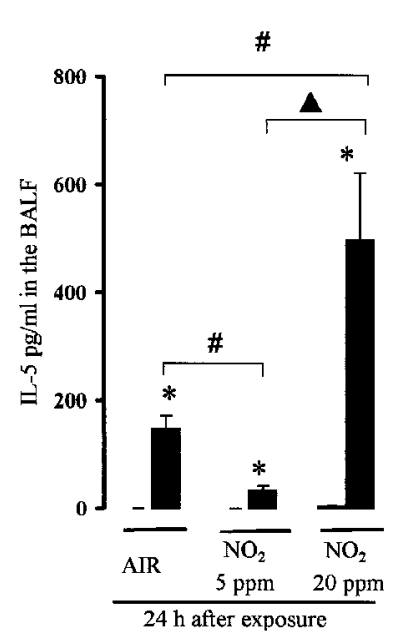

A
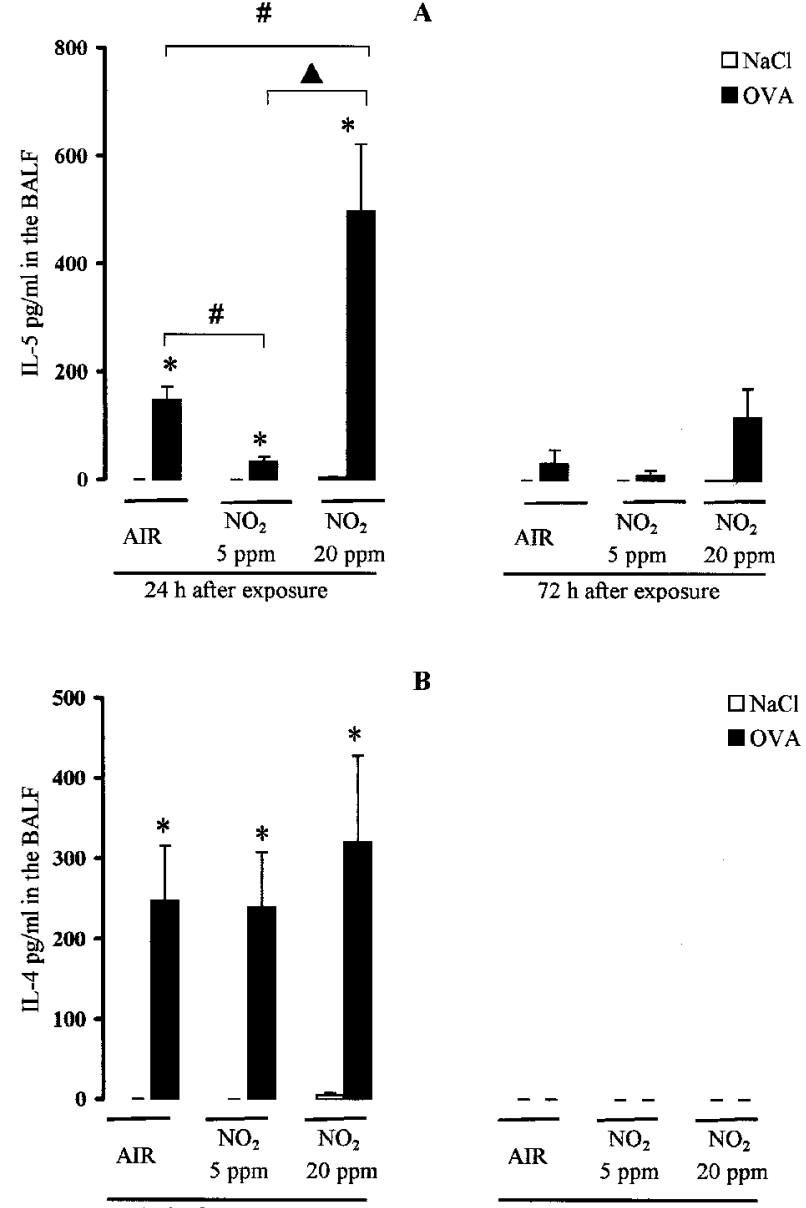

$24 \mathrm{~h}$ after exposure

B

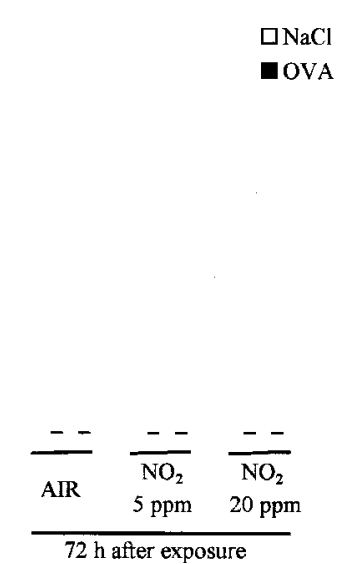

FIG. 4. BALF Th2 cytokine levels after exposures to $\mathrm{NO}_{2}$. At day 14, immunized mice were treated as in Fig. 2 (saline $(\square$ ) or OVA (ם)). Specific antibodies were evaluated in the serum by ELISA. BALF IL-4 and IL-5 content were evaluated by ELISA. (A) IL-5 and (B) IL-4. Data are expressed as the mean \pm SEM. ${ }^{*} p \leq 0.05$, OVA-challenged mice compared with their saline control; ${ }^{\#} p \leq 0.05$, OVA-air group compared with the $\mathrm{NO}_{2}$-OVA group (5 or $20 \mathrm{ppm}$ ); ${ }_{p} \leq 0.05,5 \mathrm{ppm} \mathrm{NO} \mathrm{NO}_{2}$-OVA group compared with the $20 \mathrm{ppm} \mathrm{NO} \mathrm{NO}_{2}$-OVA group.

in OVA-challenged mice exposed to $20 \mathrm{ppm}$, as compared with OVA-air mice. The increase in neutrophil counts in saline-challenged animals exposed to $20 \mathrm{ppm} \mathrm{NO} \mathrm{N}_{2}$ was also significantly above that found in saline-air or saline- $5 \mathrm{ppm} \mathrm{NO}_{2}$ mice (Fig. 3A). At $72 \mathrm{~h}$, neutrophil counts were normalized in all groups of mice (Fig. 3A). Eosinophils in the BALF were detected at $24 \mathrm{~h}$ and increased at $72 \mathrm{~h}$, with similar numbers in OVA-challenged mice exposed to air or to $20 \mathrm{ppm}$ $\mathrm{NO}_{2}$, as compared with those exposed to $5 \mathrm{ppm} \mathrm{NO}_{2}$, in which these counts were markedly reduced after 24 and $72 \mathrm{~h}$ (Fig. 3B). The EPO activity in the lung increased significantly in OVA-challenged mice exposed to air at 24 and $72 \mathrm{~h}$. OVA-challenged mice exposed to $5 \mathrm{ppm} \mathrm{NO}_{2}$ showed a marked reduction of EPO activity at 24 and $72 \mathrm{~h}$, as compared with the OVA-air group, which correlated with the reduced eosinophil counts in the BALF. Significant reduction of

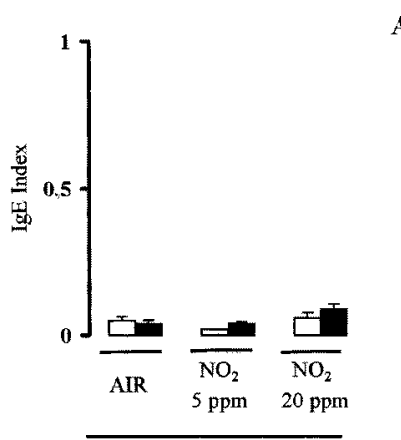

A

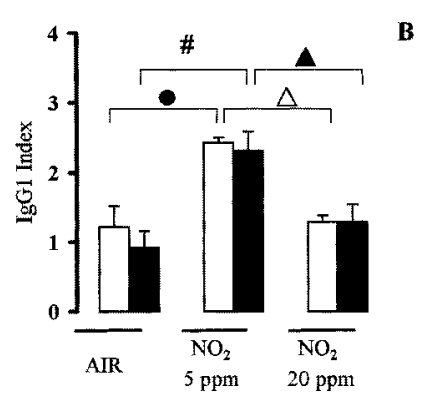

$24 \mathrm{~h}$ after exposure

B

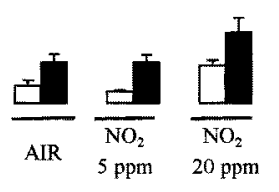

$72 \mathrm{~h}$ after exposure

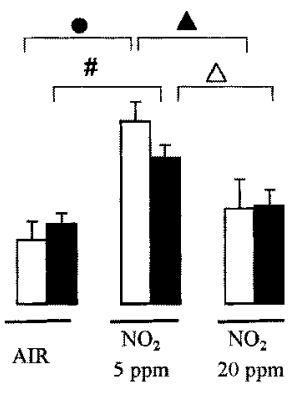

$72 \mathrm{~h}$ after exposure
FIG. 5. Specific anti-OVA $\lg E$ and $\lg G 1$ titers in the serum after exposures to $\mathrm{NO}_{2}$. At day 14, immunized mice were treated as in Fig. 2 (Saline $(\square)$ or OVA ( $\square$ )). Specific antibodies were evaluated in the serum by ELISA. (A) IgE and (B) IgG1. Data are expressed as the mean \pm SEM. ${ }^{*} p \leq 0.05$, OVA-air group compared with the $\mathrm{NO}_{2}$-OVA group (5 or $20 \mathrm{ppm}) ; \quad p \leq 0.05$, saline-air group compared with the $\mathrm{NO}_{2}-$ saline group ( 5 or $20 \mathrm{ppm}$ ); ${ }^{\wedge} \leq 0.05,5 \mathrm{ppm} \mathrm{NO} \mathrm{N}_{2}$-OVA group compared with the $20 \mathrm{ppm} \mathrm{NO}{ }_{2}$-OVA group; ${ }^{\triangle} p \leq 0.05,5 \mathrm{ppm}$ $\mathrm{NO}_{2}$-saline group compared with the $20 \mathrm{ppm} \mathrm{NO}_{2}$-saline group.

EPO activity was also noted in saline-challenged mice exposed to $5 \mathrm{ppm} \mathrm{NO}_{2}$, as compared with those exposed to air. This contrasts with results in mice exposed to $20 \mathrm{ppm} \mathrm{NO}_{2}$ or to air, in which EPO titers were increased to similar levels (Fig. 3C).

\section{Th2 cytokine production in the BALF}

OVA-challenged mice exposed to air or to $\mathrm{NO}_{2}$ released IL-5 and IL- 4 in the BALF at $24 \mathrm{~h}$. In connection with eosinophilia (cell counts and EPO in the lungs), the production of IL-5 in the BALF was significantly reduced in OVA-challenged mice $24 \mathrm{~h}$ after exposure to $5 \mathrm{ppm} \mathrm{NO}_{2}$, as compared with those exposed to $20 \mathrm{ppm} \mathrm{NO}_{2}$ or to air (Fig. 4A). However, the production of IL-5 was increased three-fold in OVA-challenged mice exposed to $20 \mathrm{ppm} \mathrm{NO}_{2}$ as compared with the OVA-air group, and was augmented by 10-fold as compared with those exposed to $5 \mathrm{ppm} \mathrm{NO}_{2}$ (Fig. 4A). By contrast, the production of IL- 4 in the BALF was increased to the same extent in the three groups $24 \mathrm{~h}$ after exposure (Fig. $4 \mathrm{~B}$ ). No IL- 4 nor IL-5 were detected in the BALF at the $72 \mathrm{~h}$ point (Fig. 4A,B). 


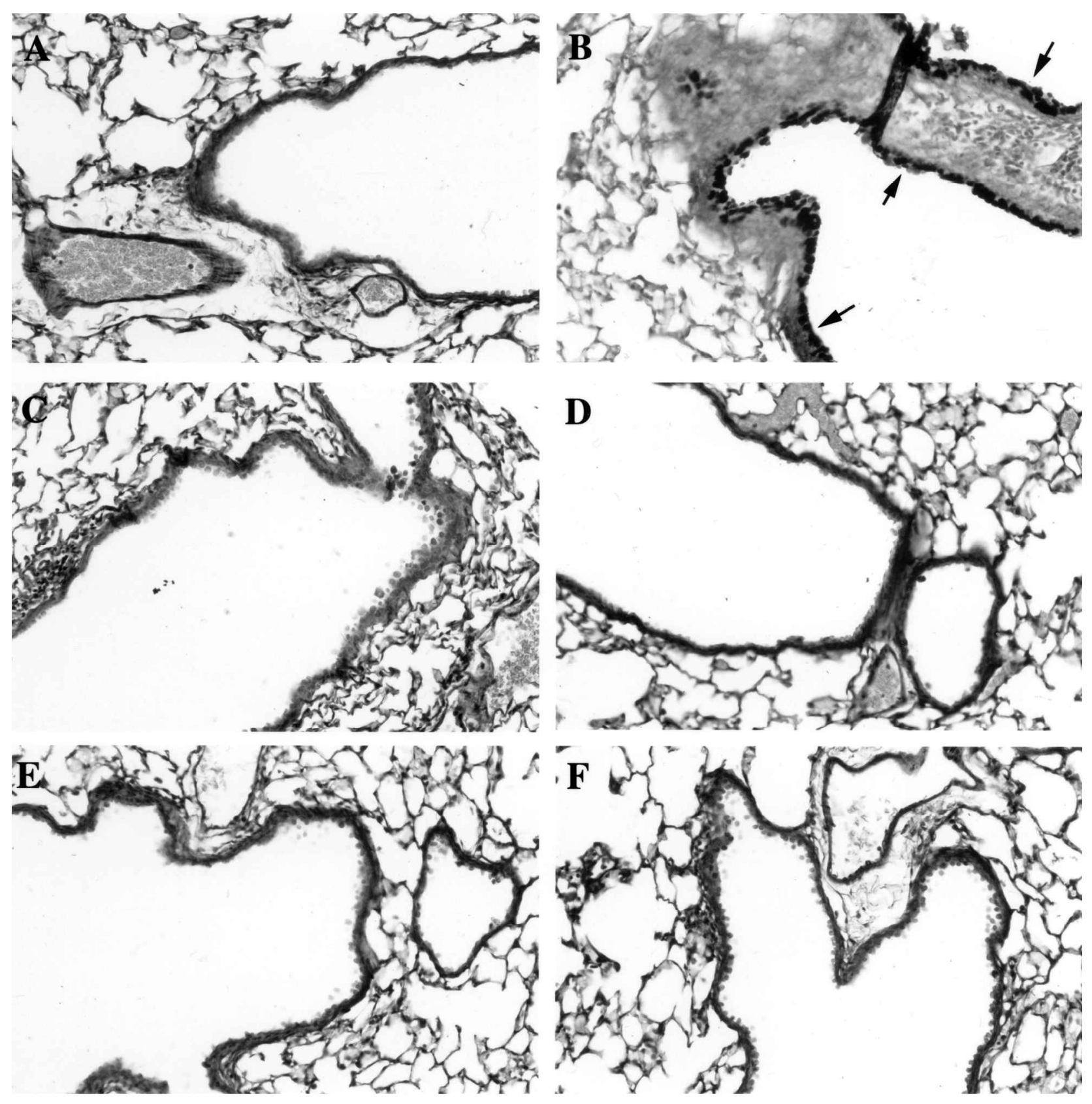

FIG. 6. Periodic acid Schiff (PAS)-stained histologic sections of lungs from allergic mice exposed to $\mathrm{NO}_{2}$. At day 14 , immunized mice were treated as in Fig. 2. Seventy hours after exposure, lungs were collected for histology. Goblet cells were stained with PAS in lung sections. (A) Lung section of saline-challenged immunized mice exposed to air. (B) Lung section of OVA-challenged immunized mice exposed to air. Note intense goblet cell hyperplasia (arrow). (C) Lung section of saline-challenged immunized mice exposed to $\mathrm{NO}_{2}$ at $5 \mathrm{ppm}$. (D) Lung section of OVA-challenged immunized mice exposed to $\mathrm{NO}_{2}$ at $5 \mathrm{ppm}$. (E) Lung section of saline-challenged immunized mice exposed to $\mathrm{NO}_{2}$ at $20 \mathrm{ppm}$. (F) Lung section of OVA-challenged immunized mice exposed to $\mathrm{NO}_{2}$ at $20 \mathrm{ppm}$. Note the absence of goblet cell hyperplasia in saline-challenged mice exposed to air or $\mathrm{NO}_{2}$ in $(A),(C)$ and $(E)$, and in OVA-challenged mice exposed to irrespective of the concentration of $\mathrm{NO}_{2}$ in (D) and (F) (final magnification, $\times 60$ ).

Production of $\lg E$ and $\lg G 1$ anti-OVA antibody in the serum

Saline- and OVA-challenged mice exposed to air or to $\mathrm{NO}_{2}$ produced specific IgE and IgG1 detected in the serum 24 and $72 \mathrm{~h}$ later. The anti-OVA IgE titers increased to a similar extend in the three groups after $72 \mathrm{~h}$ (Fig. 5A), and both concentrations of $\mathrm{NO}_{2}$ failed to affect their production. Specific IgG1 titers were markedly increased as compared with IgE, without significant differences between saline and OVA-challenged mice. Mice exposed to $5 \mathrm{ppm} \mathrm{NO}_{2}$ and challenged with saline or OVA showed a significant increase of IgG1 titers as compared with those exposed to air or to $\mathrm{NO}_{2}$ at $20 \mathrm{ppm}$ (Fig. 5B). 


\section{Histological analysis}

As expected, the bronchial epithelium of salinechallenged immunized mice exposed to air was mucus free (Fig. 6A), under conditions where that of immunized and OVA-challenged mice was markedly enriched in mucosal cells (Fig. 6B). Saline- or OVAchallenged immunized mice exposed to $\mathrm{NO}_{2}$ at 5 or $20 \mathrm{ppm}$ did not develop mucosal metaplasia as compared with OVA-challenged mice exposed to air (Fig. 6D,F).

\section{Discussion}

Studies in asthmatics have shown that air pollutants such as ozone, ${ }^{30}$ or $\mathrm{NO}_{2}$ augment the allergic responses. ${ }^{24,27,37,38}$ At high concentrations, $\mathrm{NO}_{2}$ is a well-known airway irritant that can cause bronchial constriction in normal subjects, ${ }^{17,39}$ and enhance airway responsiveness to histamine ${ }^{40}$ or methacholine $\mathrm{e}^{16}$ in asthmatic patients, which are more sensitive than healthy subjects. By contrast, few studies have addressed to the interaction between $\mathrm{NO}_{2}$ and lung allergy in experimental animals. As shown here, a short-term exposure to $\mathrm{NO}_{2}$ produces contrasting effects on the development of asthma-related responses in an OVA-immunized mouse model, which depend on the dose of $\mathrm{NO}_{2}$. Thus, the high dose of $20 \mathrm{ppm}$ potentiated BHR, exudation and release of IL5 in the BALF after OVA challenge, under conditions where the low dose of $5 \mathrm{ppm}$ failed to modify BHR, and reduced significantly pulmonary eosinophilic inflammation and the production of IL-5 in the BALF. Since a single exposure to $\mathrm{NO}_{2}$ was used here, both doses were relatively high as compared with those encountered in the environment. It has been reported, nevertheless, that the final amounts delivered to the lungs are quite below the concentrations inhaled..$^{35,36}$

The potentiation of BHR by $20 \mathrm{ppm} \mathrm{NO}_{2}$ in allergic mice may be accounted for by an increased vascular/ epithelial permeability, facilitating the allergen availability and accelerating the inflammatory process. $\mathrm{NO}_{2}$ is a potent tissue-soluble oxidant, which can induce pulmonary edema at high concentrations. In our experiments, immunized animals treated with saline and exposed to $20 \mathrm{ppm} \mathrm{NO}_{2}$ had increased titers of fibronectin in the BALF, which was used as an indicator of permeability, as compared with the saline-air or saline-5 ppm $\mathrm{NO}_{2}$ groups. The high concentration of $\mathrm{NO}_{2}$ potentiated the effects of OVA, since the fibronectin BALF content was significantly increased in OVA-challenged mice exposed to $20 \mathrm{ppm}$, as compared with the OVA-air or OVA-5 ppm $\mathrm{NO}_{2}$ groups, and correlated with the increased BHR. Even though BHR disappeared with time, the increased permeability persisted $72 \mathrm{~h}$ after exposure to $20 \mathrm{ppm}$, whereas a more delayed increase in exudation was observed in OVA-challenged mice exposed to air or to $5 \mathrm{ppm}$ of $\mathrm{NO}_{2}$. The low concentration of $\mathrm{NO}_{2}$ had an effect similar to that of OVA alone. Since our mice underwent a single exposure to $\mathrm{NO}_{2}$, it is possible that such low concentrations of $\mathrm{NO}_{2}$ become effective on repeated exposures. In this context, the most probable mechanism for $\mathrm{NO}_{2}$-induced increase in bronchial sensitivity to inhaled allergens is the damage of epithelial cells mediated by its oxidative activity, which may increase the cell permeability to the allergen, thus increasing its delivered dose, as occurs in cultured human epithelial cell monolayers exposed to $\mathrm{NO}_{2}$ over short periods. ${ }^{41}$ This would account for the augmented fibronectin titers in the BALF, after its exudation from the plasma. It is also possible that $\mathrm{NO}_{2}$ acts as a permissive agent, by allowing other factors to exacerbate asthma, or that underlying factors such as the intensity of allergy or inflammation may be a prerequisite for the expression of the detrimental effects of the gas. Finally, $\mathrm{NO}_{2}$ can reduce the mucociliary activity of the airways in vivo ${ }^{42}$ and in vitro, ${ }^{41}$ further enhancing the accessibility of the allergen to the epithelial cells, owing to its decreased clearance from the airways.

In our experiments, eosinophilia (cell counts and EPO lung content) and IL-5 in the BALF were significantly reduced in OVA-challenged mice exposed to $5 \mathrm{ppm} \mathrm{NO} \mathrm{N}_{2}$. By contrast, $20 \mathrm{ppm} \mathrm{NO} \mathrm{N}_{2}$ did not affect eosinophilia, under conditions where the production of IL-5 in the BALF was significantly increased as compared with the OVA-air group. Recently, Morris et al. ${ }^{43}$ reported that the exposure to $0.7 \mathrm{ppm} \mathrm{NO}_{2}$ reduces eosinophilic inflammation in allergic mice, but the IL-5 levels were not measured. The mechanisms of the decreased eosinophilic inflammation and IL-5 production in mice exposed to $5 \mathrm{ppm} \mathrm{NO}_{2}$ are unknown. They may result from alterations in the regional deposition patterns of OVA and of $\mathrm{NO}_{2}$ in the airways, or in absorbance, pulmonary clearance or antioxidant defenses. Indeed, $\mathrm{NO}_{2}$ has a low solubility, and is poorly absorbed by the airway mucosa. ${ }^{44}$ It is also a very reactive molecule whose uptake in the respiratory system is extremely high. ${ }^{44}$ The use of mathematical dosimetry models suggests that the uptake of $\mathrm{NO}_{2}$ between the trachea and the respiratory zone occurs to a similar extent, and peaks at the terminal bronchioles. ${ }^{44}$ It is also possible that the biphasic effect of 5 and $20 \mathrm{ppm} \mathrm{NO}_{2}$ may result from pharmacodynamic alterations. Some studies have indeed demonstrated that $\mathrm{NO}_{2}$ affects lung defense mechanisms, including mucociliary clearance, alveolar macrophages (AM), and the immune system. ${ }^{45}$ The decreased OVA-induced IL-5 production and eosinophilia after an exposure to $5 \mathrm{ppm} \mathrm{NO}_{2}$ may result from an alteration of AM function, including differences in antigen presentation by AM, or from a 
decreased expression of antigen-derived peptides on their surface, which may be hampered by exposure to $\mathrm{NO}_{2}$. Indeed, Kineast et al. ${ }^{46}$ and Erroi et al. ${ }^{47}$ have shown that $\mathrm{NO}_{2}$ exposure of LPS-stimulated human AM results in a functional impairment of AM. Furthermore, Robison et al. ${ }^{21}$ demonstrated that exposure rates to $0.5 \mathrm{ppm} \mathrm{NO}_{2}$ for $0.5-10$ days reduces the arachidonate metabolism and superoxide production in response to external stimuli. Thus, $\mathrm{NO}_{2}$ may reduce the capacity of AM to respond to immunologic stimuli, which might explain the decreased allergic responses in animals exposed to $5 \mathrm{ppm}$, in particular eosinophilia and production of IL-5.

Airway inflammation is accompanied by mucus secretion, which contributes to airway obstruction. In our experiments, irrespective of the concentration of $\mathrm{NO}_{2}$, OVA-challenged mice did not develop mucosal metaplasia, in contrast to those exposed to air, which is probably related to mucus denaturation by $\mathrm{NO}_{2}-$ induced oxidation. The mucus layer forms a protective barrier of the airways against the effects of oxidants, which eliminates and/or scavenges the toxic components of $\mathrm{NO}_{2}$ prior to their diffusion into the airway epithelium. The lipid content of the mucus layer, in particular esterified unsaturated fatty acids, constitutes the primary scavenging oxidants. ${ }^{48}$ The latter demonstrated that the phospholipids of the mucus layer cannot offer a significant protection against inhaled $\mathrm{NO}_{2}$ and that exposure to $40 \mathrm{ppm}$ $\mathrm{NO}_{2}$ in rats induces lipid peroxidation correlated with the apparent lack of oxidant scavenging species in the mucus lining the airways.

In summary, a short-term exposure to $\mathrm{NO}_{2}$ modifies the asthma-like responses to allergenic challenge in $\mathrm{BALB} / \mathrm{c}$ mice with contrasting effects according to its concentration. Despite the relatively high concentrations of $\mathrm{NO}_{2}$ used in our investigation, as compared with those encountered in the environment, this study provides new information concerning the subtle interactions between an air pollutant and allergic disease.

ACKNOWLEDGEMENTS. This work was supported by a grant of the French Ministry of Environment.

\section{References}

1. Hartert TV, Peebles RS. Epidemiology of asthma: the year in review. Curr Opin Pulmon Med 2000; 6: 4-9.

2. Anderson HR, Ponce de Leon A, Bland JM, Bower JS, Emberlin J, Strachan DP. Air pollution, pollens, and daily admissions in London 1987-1992. Thorax 1998; 53: 842-848.

3. Morgan G, Corbett S, Wlodarczyk J. Air pollution and hospital admissions in Sydney, Australia, 1990 to 1994. Am J Public Health 1998; 88: 1761-1766.

4. Sheppard L, Levy D, Norris G, Larson TV, Koenig JQ. Effects of ambient air pollution on nonelderly asthma hospital admissions in Seattle, Washington, 1987-1994. Epidemiology 1999; 10: 23-30.

5. Koren HS. Associations between criteria air pollutants and asthma. Environ Health Perspect 1995; 103: 235-242.

6. Djukanovic R, Roche WR, Wilson JW, Beasley CR, Twentyman OP Howarth PH, Holgate ST. Mucosal inflammation in asthma. Am Rev Respir Dis 1990; 142: 434-457.
7. Nakajima H, Iwamoto I, Tomoe S, Matsumura R, Tomioka H, Takatsu K, Yoshida S. CD4 ${ }^{+}$T-lymphocytes and interleukin-5 mediate antigeninduced eosinophil infiltration into mouse trachea. Am Rev Respir Dis 1992; 146: 374-382.

8. Robinson DS, Hamid Q, Ying S, Tsicopoulos A, Barkans J, Bentley AM, Corrigan C, Durham SR, Kay AB. Predominant TH2-like bronchoalveolar T-lymphocyte population in atopic asthma. $N$ Engl J Med 1992; 326: 298-304.

9. Bochner BS, Undem BJ, Lichtenstein LM. Immunological aspects of allergic asthma. Annu Rev Immunol 1994; 12: 295-335.

10. Lopez AF, Sanderson CJ, Gamble JR, Campdell HD, Young IG, Vadas MA. Recombinant human interleukin 5 is a selective activator of human eosinophil function. J Exp Med 1988; 167: 219-224.

11. Abehsira-Amar O, Gibert M, Joliy M, Theze J, Jankovic DG. IL-4 plays a dominant role in the differential development of Th0 into Th1 and Th2 cells. J Immunol 1992; 148: 3820-3829.

12. Paul WE. Interleukin-4: a prototype immunoregulatory lymphokine. Blood 1991; 77: 1859-1870.

13. American Thoracic Society (ATS), Committee of the Environmental and Occupational Health Assembly. Health effects of outdoor air pollution: Part 2. Am J Respir Crit Care Med 1996; 153: 477-498.

14. Goldstein IF, Lieber K, Andrews LR, Kazembe F, Foutrakis G, Huang P, Hayes C. Acute respiratory effects of short-term exposures to nitrogen dioxide. Arch Environ Health 1988; 43: 138-142.

15. Norman V, Keith CH. Nitrogen oxides in tobacco smoke. Nature 1965 205: 915-916.

16. Mohesin V. Airway responses to nitrogen dioxide in asthmatics subjects. J Toxicol Environ Health 1987; 22: 371-380.

17. Hajela R, Janigan DT, Landrigan S, Boudreau S, Sebastian S. Fatal pulmonary edema due to nitric acid fume inhalation in three pulp-mill workers. Chest 1990; 97: 487-489.

18. Sandstrom T, Stjernberg N, Eklund A, Ledin M, Bjermer M, KolmodinHedman B, Lindstrom K, Rosenhall L, Angstrom T. Inflammatory cell response in bronchoalveolar lavage fluid nitrogen dioxide exposure of healthy subjects: a dose response study. Eur Respir J 1991; 3: 332-339.

19. Hubbard AK, Vetrano KM, Morris JB. Acute $\mathrm{NO}_{2}$ exposure alters inflammatory cell activation and particle clearance in silica-injected mice. I Toxicol Environ Health 1994; 41: 299-314.

20. Davis JK, Davison MK, SchoebTR, Lindsey JR. Decreased intrapulmonary killing of Mycoplasma pulmonis after short-term exposure to $\mathrm{NO}_{2}$ is associated with damage alveolar macrophages. Am Rev Respir Dis 1992; 145: 406-411.

21. Robison TW, Murphy JK, Beyer LL, Richters A, Forman H. Depression of stimulated arachidonate metabolism and superoxide production in rat alveolar macrophages following in vivo exposure to $0.5 \mathrm{ppm} \mathrm{NO}_{2} . J$ Toxicol Environ Health 1993; 19: 555-568.

22. Postlethwait EM, Bidani A. Mechanisms of pulmonary $\mathrm{NO}_{2}$ absorption. Toxicology 1994; 89: 217-237.

23. Ostro BD, Lipsett M, Mann JK, Wiener MB, Selner J. Indoor air pollution and asthma. Results from a panel study. Am J Respir Crit Care Med 1994 149: $1400-1406$

24. Tunnicliffe WS, Burge PS, Ayres JG. Effect of domestic concentrations of nitrogen dioxide on airway responses to inhaled allergen in asthmatic patients. Lancet 1994; 344: 1733-1736.

25. Castellsague J, Sunyer J, Saez M, Anto JM. Short-term association between air pollution and emergency room visits for asthma in Barcelona. Thorax 1995; 50: 1051-1056.

26. Rossi OVJ, Kinnula VL, Tienari J, Huhti E. Association of severe asthma attacks with weather, pollen, and air pollutants. Thorax 1993; 48: $244-248$.

27. Strand V, Rak S, Svartengren M, Bylin G. Nitrogen dioxide exposure enhances asthmatic reaction to inhaled allergen in subjects with asthma. Am J Respir Crit Care Med 1997; 155: 881-887.

28. Strand V, Salomonsson P, LunDahl J, Bylin G. Immediate and delayed effects of nitrogen dioxide exposure at an ambient level on bronchial responsiveness to histamine in subjects with asthma. Eur Respir J 1996; 9: $733-740$.

29. Samet JM, Lambert WE, Skipper BJ, Cushing AH, Hunt WC, Young SA, McLaren LC, Schwab M, Spengler JD. Nitrogen dioxide and respiratory illnesses in infants. Am Rev Respir Dis 1993; 148: 1258-1265.

30. Molfino NA, Wright SC, Katz I, Tarlo S, Silverman F, McClean PA, Szalai JP, Raizenne M, Slutsky AS, Zamel N. Effect of low concentrations of ozone on inhaled allergen responses in asthmatic subjects. Lancet $1991 ; 338$ : 199-203.

31. Hamelmann E, Schwarze J, Takeda K, Oshiba A, Larsen GL, Irvin CG, Gelfand EW. Noninvasive measurement of airway responsiveness in allergic mice using barometric plethysmography. Am J Respir Crit Care Med 1997; 156: 766-775.

32. Van Oosterhout AJM, Fattah D, Van Ark I, Hofman G, BuckleyTL, Nijkamp FP. Eosinophil infiltration precedes development of airway hyperreactivity and mucosal exudation after intranasal administration of interleukin-5 to mice. J Allergy Clin Immunol 1995; 96: 104-112.

33. Eum SY, Zuany-Amorim C, Lefort J, Pretolani M, Vargaftig BB. Inhibition by the immunosuppressive agent FK-506 of antigen-induced airways eosinophilia and bronchial hyperreactivity in mice. Br J Pharmacol 1995; 120: $130-136$ 
34. Rennard SI, Berg R, Martin GR, Foidart JM, Gehron Robey P. Enzymelinked Immunoassay (ELISA) for connective tissue components. Anal Biochem 1980; 104: 205-214.

35. Hatch GE, Slade R, Harris LP, Mc Donnell WF, Devlin RB, Koren HS, Costa DL, McKee J. Ozone dose and effect in human and rats. A comparison using oxigen-18 labeling and bronchoalveolar lavage. Am J Respir Crit Care Med 1994; 150: 676-683.

36. Kleeberger RS, Zhang LY, Jakab GJ. Differential susceptibility to oxidant exposure in inbred strains of mice: nitrogen dioxide versus ozone. Inhal Toxicol 1997; 9: 601-621.

37. Jenkins HS, Devalia JL, Mister RL, Bevan AM, Rusznak C, Davies JR. The effect of exposure to ozone and nitrogen dioxide on the airway response of atopic asthmatics to inhaled allergen. Am J Respir Crit Care Med 1999; 160: 33-39.

38. Strand V, Svartengren M, Rak S, Barck C, Bylin G. Repeated exposure to an ambient level of $\mathrm{NO}_{2}$ enhances asthmatic response to a non symptomatic allergen dose. Eur Respir J 1998; 12: 6-12.

39. Mohesin V. Airway response to $2.0 \mathrm{ppm}$ nitrogen dioxide in normal subjects. Arch Environ Health 1988; 43: 242-246.

40. Bylin G, Hedenstierna G, Lindvall T, Sundin B. Ambient nitrogen dioxide concentrations increase bronchial responsiveness in subjects with mild asthma. Eur Respir J 1988; 1: 606-612.

41. Devalia JL, Sapsford RJ, Cundell DR, Rusnak C, Campbell AM, Davies RJ. Human bronchial epithelial cell dysfunction following in vitro exposure to nitrogen dioxide. Eur Respir J 1993; 6: 1308-1316.

42. Helleday R, Huberman D, Blomberg A, Stjernberg N, Sandstrom $T$ Nitrogen dioxide exposure impairs the frequency of the mucociliary activity in healthy subjects. Eur Respir J 1995; 8: 1664-1668.

43. Morris JB, Olson JE, Symanowicz PT, Thrall RS, Cloutier MM, Hubbard AK. Effect of nitrogen dioxide on ovalbumin-induced allergic airway disease in a murine model [abstract]. Am J Respir Crit Care Med 2001; 163: A432.

44. Chitano P, Hosselet JJ, Mapp CE, Fabbri LM. Effect of oxidant air pollutants on the respiratory system insights from experimental animal research. Eur Respir J 1995; 8: 1357-1371.

45. O'Neill CA, Van der Vliet A, Eiserich JP, Last JA, Halliwell B, Cross CE. Oxidative damage by ozone and nitrogen dioxide: synergistic toxicity $i n$ vivo but no evidence of synergistic oxidative damage in an extracellular fluid. Biochem Soc Symp 1995; 61: 139-152.

46. Kineast K, Knorst M, Müller-Quernheim J, Ferlinz R. Modulation of IL-1 $\beta$ IL-6, IL-8, TNF- $\alpha$, and TGF- $\beta$ secretions by alveolar macrophages under $\mathrm{NO}_{2}$ exposure. Lung 1996; 174: 57-67.

47. Erroi A, Pagani P, Sironi M, Salmona M. In vivo exposure to $\mathrm{NO}_{2}$ reduces TNF and IL- 6 production by endotoxin-stimulated alveolar macrophages. Am J Physiol 1996; 271: L132-L138.

48. Cavanagh DG, Morris JB. Mucus protection and airway peroxidation following nitrogen dioxide exposure in the rat. J Toxicol Environ Health 1987; 22: $313-328$.

\section{Received 7 May 2002}

Accepted 13 May 2002 


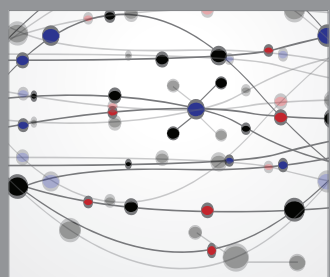

The Scientific World Journal
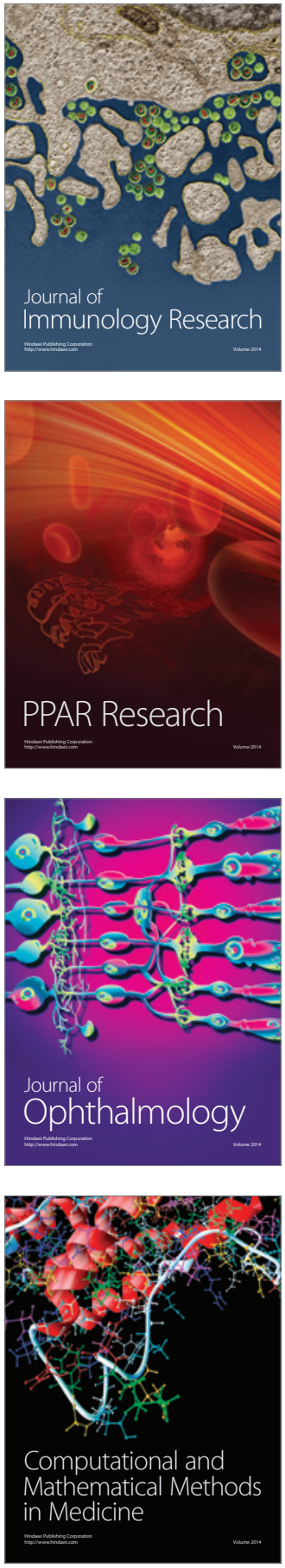

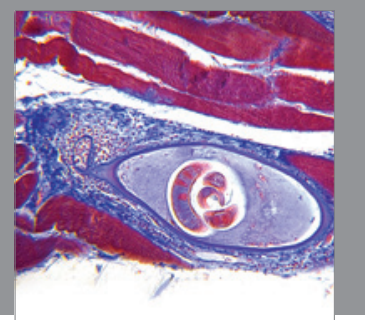

Gastroenterology

Research and Practice
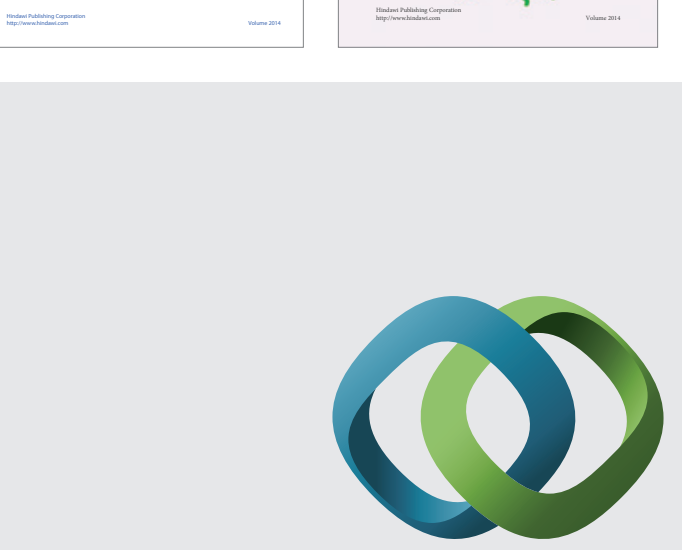

\section{Hindawi}

Submit your manuscripts at

http://www.hindawi.com
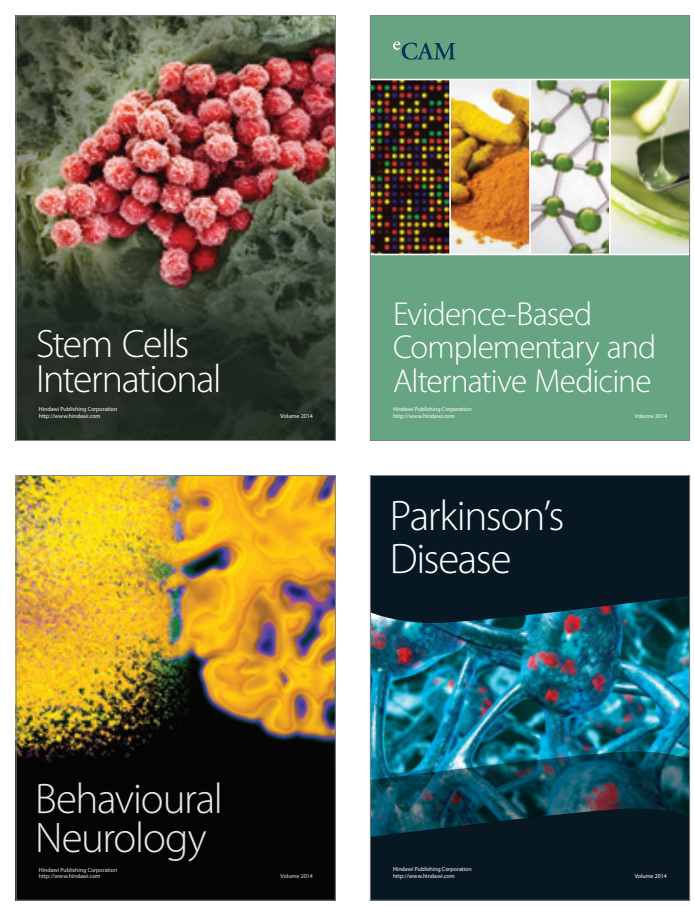

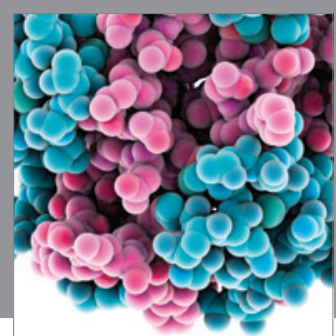

Journal of
Diabetes Research

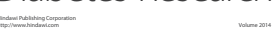

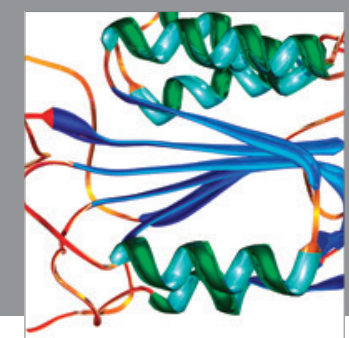

Disease Markers
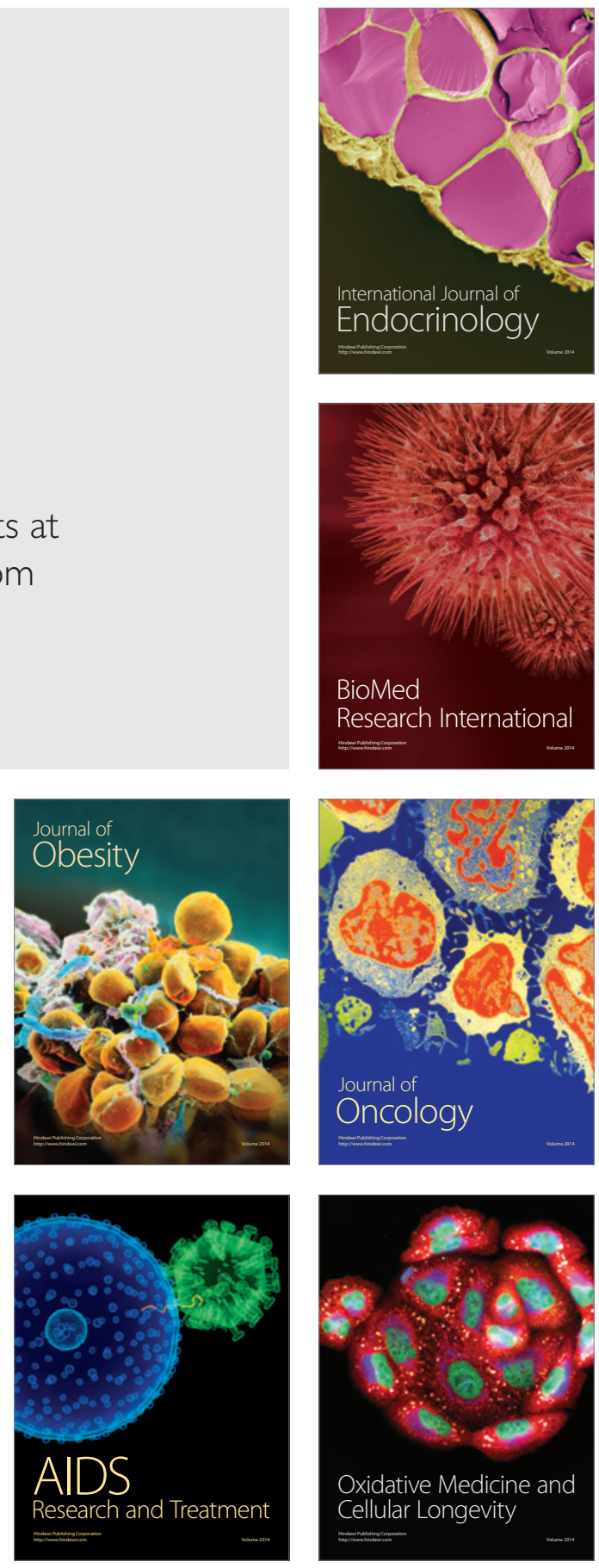